\title{
Enhancing power output and profitability through energy-efficiency techniques and advanced materials in today's industrial gas turbines
}

\author{
Zainul Huda1*, Tuan Zaharinie ${ }^{2}$ and Hany A Al-Ansary ${ }^{3}$
}

\begin{abstract}
This paper reviews and integrates the latest energy-efficiency improvement techniques to recently developed superalloys and coatings for enhancing power output and profitability in today's industrial gas turbines (GTs). It has been shown that the retrofitting of inlet air cooling and steam injected gas technology technologies in simple turbines can boost power output from 30 to $48.25 \mathrm{MW}$ and improve generation efficiency from $29.9 \%$ to $33.4 \%$. It has been reviewed that for improving efficiency of power plants beyond 60\%, it is important to use higher turbine inlet temperature (TIT) in combined cycle gas turbine by applying single-crystal nickel-based superalloys and thermal barrier coating involving closed-loop steam cooling. It has been shown that an increase of the TIT by $56^{\circ} \mathrm{C}$ can result in increased revenue of US\$8/kW to the manufacturer of the original rating, provided the GT is sold for US\$200/kW. In view of the latest development in GT technology, which enables them to be operated at $\mathrm{TIT}=1,600^{\circ} \mathrm{C}$, it is recommended to develop superalloys based on higher-melting temperatures (Mo-based superalloys). A new chart for increasing power output has been developed so as to enable the GT designers to manufacture GT engines with enhanced profitability.
\end{abstract}

Keywords: Energy efficiency; Gas turbine; Combined cycle power plants; Inlet air cooling; Advanced superalloys; Thermal barrier coatings

\section{Review}

\section{Introduction}

There has been an increasing trend in saving energy costs for power generation in developing countries. The gasturbine (GT)-based power plant is characterized by its relatively low capital cost as compared to the steam power plant. However, conventional industrial GT engines have lower efficiencies, especially at part load, which cause emission and environmental related problems. Electric power generation is one of the main contributors to emissions and imparts adverse effects on the environment thereby influencing human health, organism growth, climatic changes, and the like (Mahlia 2002). One of the technologies applied nowadays for efficiency improvement and clean power generation (with reduced emission) is the 'combined cycle' (CC) (Yokoyama et al. 2004; Larson and Marrison 1997). The thermal efficiency of combined cycle gas turbine

\footnotetext{
* Correspondence: drzainulhuda@hotmail.com

${ }^{1}$ Department of Engineering (Mechanical Engineering Program), Nilai University, Nilai, Negeri Sembilan 71800, Malaysia

Full list of author information is available at the end of the article
}

(CCGT) power plants can reach 60\% that is far more than that of conventional coal-fired steam turbine plants. The CCGT power plants not only conserve our limited reserves but also reduce emissions and protect our lives and environment (Balat 2010; De Biasi 2002). Even substantially higher efficiency is possible in a cogeneration plant, where excess generated heat is put to use for process or domestic heating, in addition to electric power generation (UNESCAP 2000).

A review of recent advances in gas-turbine technology shows outstanding developments in its major components (Gorji-Bandpy et al. 2010; Najjar and Zaamout 1996; Huda 2009, 2007, 1995). Superalloy and coating advancements for application in hot sections of gas turbine engines have resulted in a considerable economic leverage in power plants (Miller and Chambers 1987; Reed 2006). The modern CCGT uses single-crystal (SC) superalloys and special thermal barrier coatings (TBCs) and - in one design closed-loop steam cooling to reach more than $60 \%$ thermal 
efficiency. The application of advanced superalloys in the hot sections of modern gas-turbines also enables higher temperature operation. The operating temperatures in the first-stage and second-stage SC blades in modern CCGT lie in the ranges of $1,300^{\circ} \mathrm{C}$ to $1,500^{\circ} \mathrm{C}$ and $1,000^{\circ} \mathrm{C}$ to $1,100^{\circ} \mathrm{C}$, respectively (see 'Techniques to improve efficiency of GT engines' section for details). For example, General Electric (GE) Inc. USA's H-turbine (Fairfield, CN, USA) uses SC materials in first-stage blades and vanes that operate at a temperature of $1,430^{\circ} \mathrm{C}$ over a long service life. Similarly, first-stage turbine blades of Siemens' SGT5-8000H machine (Siemens AG, Munich, Germany) are made of specialized high-temperature alloy material to combat long-term effects of high temperatures at constant stress (to resist creep deformation).

The application of TBCs on gas turbine components provides a potential opportunity for increasing the operating temperature and further enhances the life of components (Martin et al. 2001; Gurrappa and Sambasiva 2006). The TBCs can be used at tolerable metal temperature at constant cooling levels, and the efficiency of cooling leads to lower metal operating temperatures with extended lifetime (Stöver and Funke 1999).

\section{Improving energy efficiency of GT engines Thermodynamic approach for improving efficiency of gas turbines}

The efficiency, $\eta$, of a gas turbine engine, like that of any heat engine, may be defined as the ratio of the effective work done to the heat obtained from burning fuel:

$$
\eta=W_{\text {out }} / Q_{\text {in }}
$$

Equation 1, which is a notation of the first law of thermodynamics, can be formulated as follows: the thermal efficiency of a heat engine cannot exceed 1. A temperaturedependent relationship can be developed by application of the second law of thermodynamics (also called the CarnotClausius theorem) which states: 'The efficiency of a heat engine reversibly operating by the Carnot cycle does not depend on the nature of the machine's working medium, but only depends on the temperatures of the heater and the cooler' (Kuchling 1980). Hence, the efficiency, $\eta$, of power plant can be calculated through the temperature difference between the hot $\left(T_{\text {hot }}\right)$ and the cold $\left(T_{\text {cold }}\right)$ thermal reservoirs, as follows:

$$
\eta=\left(T_{\text {hot }}-T_{\text {cold }}\right) / T_{\text {hot }}=1-T_{\text {cold }} / T_{\text {hot }}
$$

where $T_{\text {hot }}$ is the highest temperature reached in the cycle (temperature of the heat addition), and $T_{\text {cold }}$ is the lowest temperature (temperature of the heat removed).

For a gas turbine plant operating on a working fluid as a perfect gas with constant specific heat, the thermal efficiency of the ideal Brayton cycle can be expressed by modifying Equation 2 as follows (Boyce 1982):

$$
\eta_{B}=1-T_{2} / T_{1}
$$

where $T_{1}$ is the turbine inlet temperature and $T_{2}$ is the turbine outlet temperature. Equation 3 clearly indicates that thermal efficiency can be improved by increasing the turbine inlet temperature; this thermodynamic relationship is applied to enhance profit by improving efficiency of gas turbine (GT) engines as discussed in 'Enhancing profitability in power generation' section.

\section{Techniques to improve efficiency of GT engines}

The efficiency of a Brayton engine or combined BraytonRankine engine can be improved in the following methods (Carapellucci 2009; Bassily 2008; Canière et al. 2006; Najjar 2001; Najjar et al. 2004; Brooks 2000; Agarwal et al. 2011): (a) intercooling, (b) regeneration, (c) combined cycle, (d) cogeneration, (e) higher turbine inlet temperature (TIT), (f) inlet air cooling (IAC), and (g) using steam injected gas technology (STIG) cycles.

Intercooling For intercooling, the working fluid passes through the first stage of compressors, then a cooler, followed by the second stage of compressors before entering the combustion chamber. While this requires an increase in the fuel consumption of the combustion chamber, there is a corresponding beneficial effect, as follows. The flow of working fluid through the compressor results in a reduction in the specific volume of the fluid entering the second stage of compressors, with an attendant overall decrease in the amount of work needed for the compression stage. The decrease in input work results in efficiency improvement. There is also an increase in the maximum feasible pressure ratio due to reduced compressor discharge temperature for a given amount of compression, improving overall efficiency. The working temperature of a gas turbine, necessary to achieve high efficiency, makes cooling of the first turbine stages unavoidable. Air and steam can be used for cooling.

Regeneration For regeneration, the still-warm postturbine fluid is passed through a heat exchanger to preheat the fluid just entering the combustion chamber. This directly offsets fuel consumption for the same operating conditions, improving efficiency; it also results in less power lost as waste heat.

Combined cycle A Brayton (GT) engine also forms half of the combined cycle system, which combines with a Rankine (steam) engine to further increase overall efficiency. This kind of energy-efficiency technique allows conversion of the thermal energy of the turbine exhaust gasses into 
mechanical work, obtaining the so-called gas-steam combined cycles. The thermal efficiencies of modern CCGT power plants are as high as about 60\%, which is evident from the data for a MS9001H plant as shown in Table 1 (Gorji-Bandpy et al. 2010).

Cogeneration Cogeneration systems make use of the waste heat from Brayton (GT) engines, typically for hotwater production or space heating. In a CC cogeneration, natural gas turbine is coupled with an electrical generator. The exhaust heat from the gas turbine is directed to a waste heat recovery boiler (WHRB). The steam from the WHRB is directed to a steam turbine generator where the steam can be used for power generation (see Figure 1). In a typical cogeneration plant, electric power is generated but some of the steam from the WHRB is used to process heat thereby increasing thermal efficiency.

Higher turbine inlet temperature In the preceding section, we have established by using a thermodynamic approach that thermal efficiency can be improved by increasing the TIT. The controlling parameter for thermal efficiency in turbine design is not only the turbine inlet temperature but also the exhaust gas temperature. However, this requires special cooling at the hottest section of the turbine as well as the development of better materials, including ceramics and TBCs (Pilavachi 2000). In general,

Table 1 Results of the CC plant simulation based on MS9001H ( $p_{\mathrm{PH}}=150$ bar) (Gorji-Bandpy et al. 2010)

\begin{tabular}{|c|c|c|}
\hline Element & Parameter & Value \\
\hline \multirow[t]{3}{*}{ Gas turbine } & High-pressure firing temperature, $\mathrm{TIT}_{\mathrm{HP}}(\mathrm{K})^{\mathrm{a}}$ & 1,700 \\
\hline & Flow rate, $m_{\text {out }}(\mathrm{kg} / \mathrm{s})$ & 685 \\
\hline & Power, $W_{\mathrm{s}}(\mathrm{MJ} / \mathrm{kg})$ & 339 \\
\hline \multirow[t]{10}{*}{ Steam turbine } & Specific work, W (kJ/kg) & 506 \\
\hline & High pressure, $P_{\mathrm{HP}}(\text { bar })^{\mathrm{a}}$ & 150 \\
\hline & Intermediate pressure, $P_{\mathrm{IP}, \mathrm{opt}}(\mathrm{bar})$ & 40 \\
\hline & Low pressure, $P_{\mathrm{LP}, \text { opt }}$ (bar) & 3.2 \\
\hline & Condensation pressure, $P_{\text {cond }}(\mathrm{kPa})^{\mathrm{a}}$ & 7 \\
\hline & Flow rate of high pressure, $m_{\mathrm{HP}}(\mathrm{kg} / \mathrm{s})$ & 101.1 \\
\hline & Flow rate of intermediate pressure, $m_{\mathbb{P}}(\mathrm{kg} / \mathrm{s})$ & 110.7 \\
\hline & Flow rate of low pressure, $m_{\mathrm{LP}}(\mathrm{kg} / \mathrm{s})$ & 121.6 \\
\hline & Power, W (MW) & 173 \\
\hline & Specific work, $W_{\mathrm{s}}(\mathrm{kJ} / \mathrm{kg})$ & 259 \\
\hline \multirow[t]{3}{*}{ Boiler } & Maximum steam temperature, $T_{\max }$ steam $(\mathrm{K})$ & 833 \\
\hline & Gas temperature at the exit of the HRSG, $T_{\text {out }}(K)$ & 365 \\
\hline & HRSG heat duty (MW) & 410 \\
\hline \multirow[t]{3}{*}{ Overall performances } & CC power, $W_{\text {el }}(\mathrm{MW})$ & 505 \\
\hline & CC specific work, $W_{\mathrm{s} \text {, el }}(\mathrm{kJ} / \mathrm{kg})$ & 754 \\
\hline & CC efficiency, $\eta_{\mathrm{el}}(\%)$ & 60.1 \\
\hline
\end{tabular}

${ }^{\mathrm{a}}$ Fixed values for GE's steam and gas CC power plant.

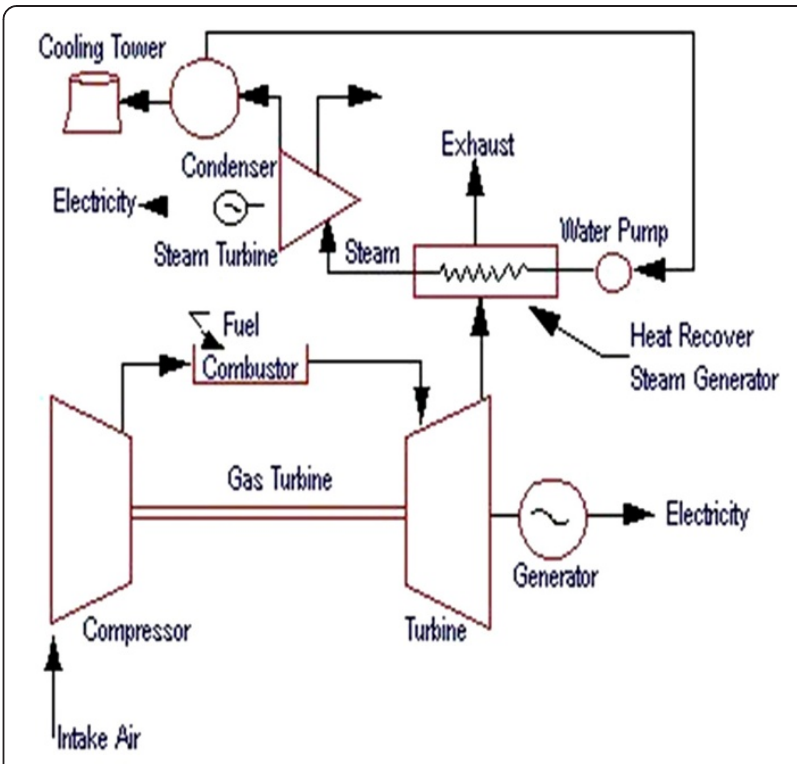

Figure 1 Combined cycle cogeneration gas turbine system.

power-generating gas-turbine plants use steam cooling in its $\mathrm{H}$ system turbine that operates as hot as $1,430^{\circ} \mathrm{C}\left(2,606^{\circ} \mathrm{F}\right)$. However, the modern trend in power-generating plants is to opt for all air-cooling because this method is considered simpler than steam cooling and offers more design flexibility by avoiding dependence on the steam cycle.

According to a survey of modern CCGT power plants, the operating temperatures in the first-stage SC blades were found to lie in the range of $1,300^{\circ} \mathrm{C}$ to $1,500^{\circ} \mathrm{C}$. This temperature range refers to the lowest value for the Alstom Power through the GE Power Systems and the Siemens to the highest value for the Mitsubishi. Recently (May 2011), Mitsubishi Heavy Industries, Ltd. (MHI), Japan has achieved the world's highest TIT of $1,600^{\circ} \mathrm{C}$, with the company's most advanced 'J-series' gas turbine (Figure 2).

The new $1,600^{\circ} \mathrm{C}$-class J-series gas turbine has achieved a rated power output of about 320 megawatts (MW) (ISO basis) and $460 \mathrm{MW}$ in gas turbine combined-cycle (GTCC) power generation applications, in which heat recovery steam generators and steam turbines are also used. The MHI has also confirmed gross thermal efficiency exceeding $60 \%$ - the world's highest level in CCGT applications.

Inlet air cooling and STIG cycles The IAC and STIG cycles are recent developments resulting in improved efficiency in industrial gas-turbines. The IAC involves cooling the air before the compression and is a proven method of increasing turbine power output, especially during peak summer demand. The IAC cycle technology reduces the temperature of the air entering the compressor section, causing the density and mass flow rate to increase, thereby increasing the power output of the gas turbine. This method is particularly useful in cases where the ambient 


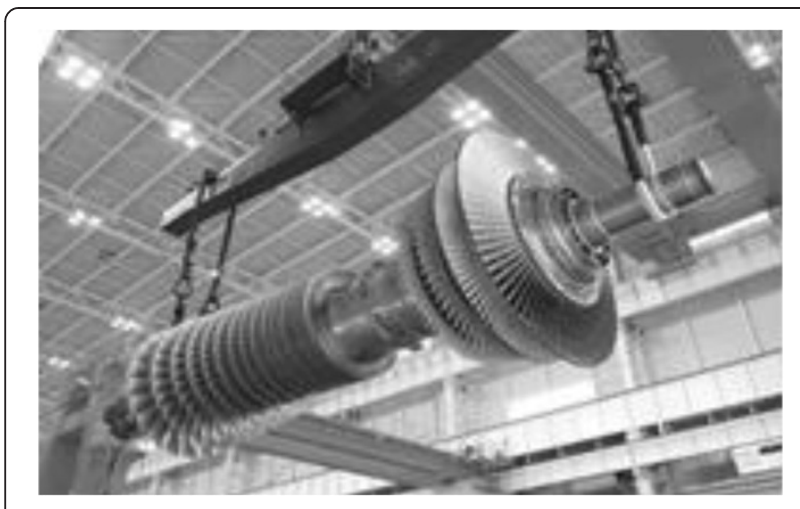

Figure $2 \mathrm{~J}$-series $\mathrm{MHI}$ gas turbine capable of operating at TIT = $1,600^{\circ} \mathrm{C}$.

temperature is high. Figure 3 shows the relationship between ambient temperature and turbine power output on a percentage basis for a typical gas turbine (Brooks 2000). The values in Figure 3 are normalized relative to the power obtained at $15^{\circ} \mathrm{C}$.

The analysis of data in Figure 3 indicates that turbine power output can increase by as much as $0.7 \%$ for every $1^{\circ} \mathrm{C}$ drop in inlet air temperature. Conversely, the gas turbine power output significantly decreases with rise in temperature, which is why the power output falls during hot summer months when the demand is at its peak. For this reason, it is highly desirable to keep the compressor inlet air temperature as low as possible by cooling the incoming ambient air.

There are two widely used IAC systems: evaporative cooling systems and chiller systems. The evaporative cooling is economical and uncomplicated. However, there are two limitations in the evaporating cooling: (a) its efficiency can significantly drop if the relative humidity is high, and (b) there is a potential for excessive wear of compressor blades if water droplets are carried into the compressor section.

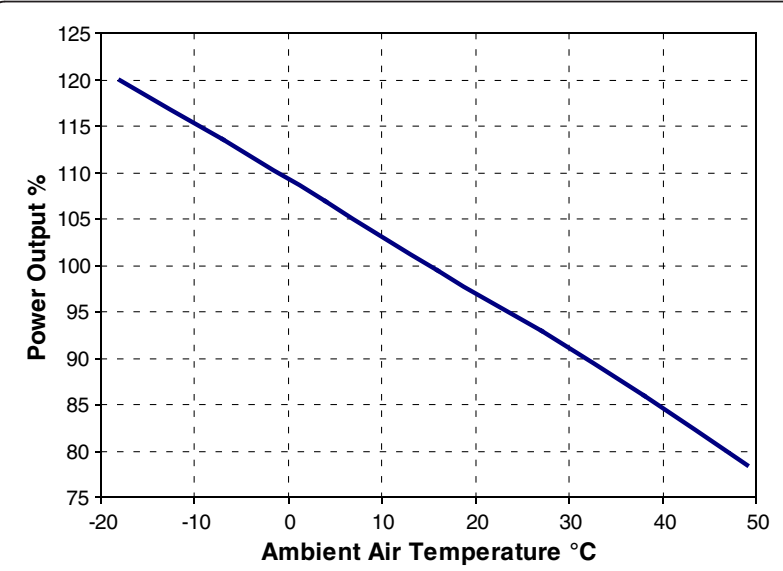

Figure 3 Variation of power output with ambient air temperature for a GE MS7001 gas turbine (Brooks 2000).
On the other hand, the chiller systems have the advantage of being independent of humidity and do not have the potential to cause damage to compressor blades. However, chiller systems consume power and cause a larger pressure drop than evaporative coolers. The coauthor (HAA) has explored a relatively new technique of turbine IAC by using an ejector refrigeration system to cool turbine inlet air; which is illustrated in Figure 4. (Al-Ansary 2007). This system (see Figure 4) involves low-maintenance and is fluid-driven with heat-operated devices that can use part of the turbine exhaust flow as the heat source for running the cycle. This system requires only pump power to feed liquid refrigerant to the vapor generator thereby significantly decreasing the power consumption.

The STIG technology involves adding steam to the combustion chamber. Recently in 2011, Agarwal et al. have reported a significant improvement in power generation capacity and efficiency of simple cycle gas turbine through IAC and STIG (Brooks 2000). In the study, a simple cycle generation unit was considered as base unit and STIG and IAC features were sequentially retrofitted to the system with the aid of computer program software to stimulate performance parameters. It has been shown that retrofitting of simple cycle combined with IAC and STIG can boost power output from 30 to $48.25 \mathrm{MW}$, while generation efficiency can be increased from $29.9 \%$ to $33.4 \%$ (Brooks 2000).

\section{Enhancing profitability in power generation}

In the gas turbine using the Brayton cycle, the hot sections (combustion and turbine parts) are in contact with a 'continuously' hot working fluid. For pursuing higher kilowatt power ratings for given sizes of industrial turbines, turbine inlet temperatures are increased (see 'Improving energy efficiency of GT engines' section). Figure 5 illustrates the relationship of the specific work output $(\mathrm{kW} \mathrm{h} / \mathrm{kg})$ with the turbine inlet temperature $\left({ }^{\circ} \mathrm{C}\right)$ in a simple Brayton cycle gas turbine.

It is evident from Figure 5 that if the TIT is increased by $56^{\circ} \mathrm{C}$, the specific work output $(\mathrm{kW} \mathrm{h/kg)}$ would be increased by $4 \%$. It means that if a gas turbine is sold for US $\$ 200 / \mathrm{kW}$ (Nye Thermodynamics Corporation 2011), an increase of $56^{\circ} \mathrm{C}$ in TIT would result in an increased revenue of US $\$ 8 / \mathrm{kW}$ of the original rating to the manufacturer. The net profit can thus be calculated as follows:

Net profit $/ \mathrm{kW}=$ Increase in revenue per $\mathrm{kW}-\left(C_{1}+C_{2}\right)$

where $C_{1}=$ additional cost $/ \mathrm{KW}$ on superalloy with increased temperature capability and $C_{2}=$ additional cost $/ \mathrm{kW}$ on gasturbine system due to increase in temperature.

A significant improvement in the thermal efficiency of gas-turbine can be achieved by combining Braton cycle 


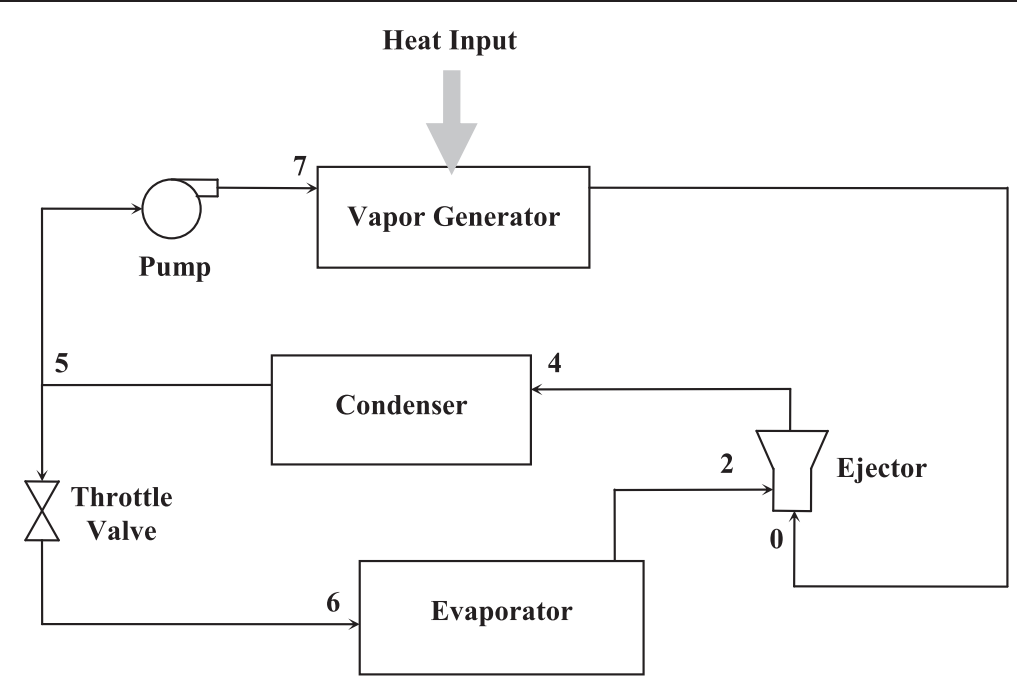

Figure 4 Schematic of a an ejector refrigeration system (AI-Ansary 2007).

with other cycles (e.g., Rankine cycle). Figure 6 shows that thermal efficiency of a Brayton-Rankine cycle could be increased $2.25 \%$ by increasing TIT by $56^{\circ} \mathrm{C}$.

In an industrial gas turbine, about $0.04 \mathrm{~kg}$ of superalloy is used in the hot section per kilowatt of power produced. About $2 \%$ of the cost of turbines in such a power plant is due to the use of superalloys. For example, we consider a case study of electric power generation whereby one finds that the average cost of the power plant was taken as around 7.5 mills $/ \mathrm{kW} \mathrm{h}(0.75$ cents $/ \mathrm{kW}$ h) (Zeren 1982). A fuel cost of 7.5 cents $/ \mathrm{kW}$ h was found to be reasonable. It is evident from Figure 6 and the cost data that if an increase of $22.5 \%$ in the plant cost permitted this TIT rise (of $56^{\circ} \mathrm{C}$ ), a break-even condition would exist at these fuel and plant costs. Despite of the increase in the plant cost, the plant is economically feasible and profitable because the operation management of gas-turbine (GT) power plant is becoming more competitive and since the energy (fuel) resources are becoming increasingly scarce and limited.

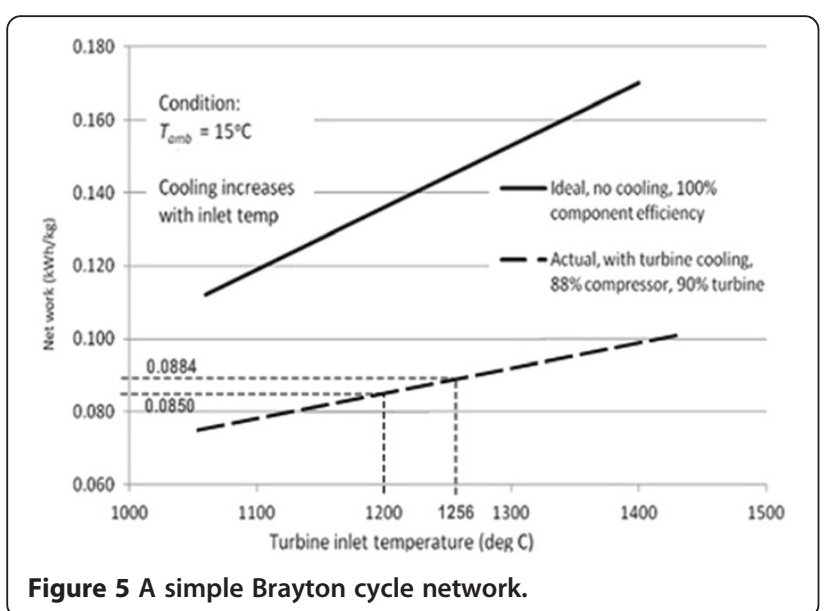

In view of the discussion in the preceding paragraphs, it is important to look for advanced energy-efficient superalloys and coatings which enable us to operate gas-turbine engines at higher TITs. These advanced materials (superalloys) and coatings are discussed in the following sections.

\section{Improving GT efficiency through advanced superalloys GT operating conditions and advanced superalloys}

Modern gas turbine engines require a significant increase of gas inlet temperatures in order to achieve maximum efficiency. This results in an increased service temperature and consequently in enhanced high-temperature corrosion attack of the blade materials. The blades in modern aero, marine, and industrial gas turbines are manufactured exclusively from nickel-based super alloys and operate under the most arduous conditions of temperature and stress of any component in the engine (Huda 2009, 1995). These conditions are further complicated for turbine installations in marine (corrosive) environments, which include sulfur and

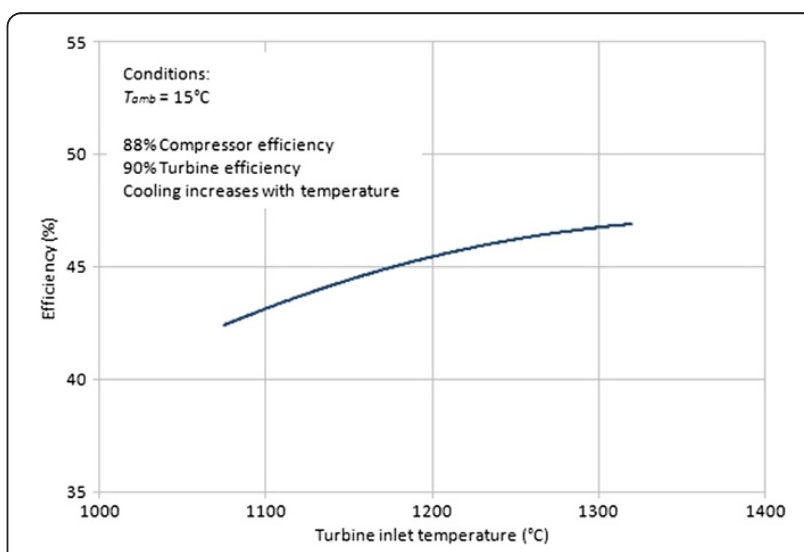

Figure 6 Brayton-Rankine cycle efficiency. 
sodium from the fuel and various halides contained in seawater (Schulz et al. 2008; Braue et al. 2007). These features are known to drastically reduce the superalloy component life and reliability by consuming the material at an unpredictably rapid rate, thereby reducing the load-carrying capacity and potentially leading to catastrophic failure of components. Thus, in order to improve the efficiency of a gas turbine engine significantly, the hot corrosion resistance of superalloys is as important as its high-temperature strength in gas turbine engine applications (Gurrappa and Sambasiva 2006). The nickel-based superalloys possess excellent high-temperature creep resistance, thermal stability, good tensile strength, long fatigue life, microstructural stability at high temperature, as well as good resistances to oxidation and corrosion (Huda et al. 2011). For these reasons, they are used in the manufacturing of gas turbine hot components (Huda 2009, 2007; Reed 2006; Jianting 2011; Cao and Loria 2005).

\section{Alloy development for hotter GT engines}

We have established in the preceding section that besides other important alloy characteristics, the high-temperature creep resistance is the primary requirement in superalloys for hotter GT engines. The first author $(\mathrm{ZH})$ has reported design principles for developing creep-limited alloys for hot sections (particularly blades) of gas turbines (Huda 2007, 1995). We will now discuss some recently developed alloys for hotter industrial gas-turbine engines. A number of advanced superalloys have been developed for GT blades during the last two decades; these include the SC superalloys (AM1, René N6, MC538, etc.), the GTD-111 superalloy, the Allvac 718Plus superalloy, and the like (Sajjadi and Nategh 2001; Sajjadi et al. 2002, 2006; Zickler et al. 2009). Although these advanced alloys are nickel-based, new alloys based on metals with higher-melting temperatures (e.g., molybdenum (Mo) and niobium ( $\mathrm{Nb}$ ) alloyed with silicon) can also be prospective candidates for hotter GT engines (Perepezko 2009). This future trend is also evident in Figure 7 which illustrates the development of advanced superalloys in the temperature capacity of the alloys since 1940 .

Figure 7 not only focuses on nickel-based superalloys for gas-turbine engine applications but also demonstrates the need for developing new energy-efficient superalloys, such as Mo-based superalloys for achieving further technological gains.

Table 2 presents the chemical composition of some energy-efficient GT blade Ni-based superalloys (Zickler et al. 2009; Todd 1989). The effect of the composition on materials characteristics of various superalloys is discussed in the following subsections.

Single-crystal blade superalloys The use of SC highpressure turbine blades made of nickel-based superalloys

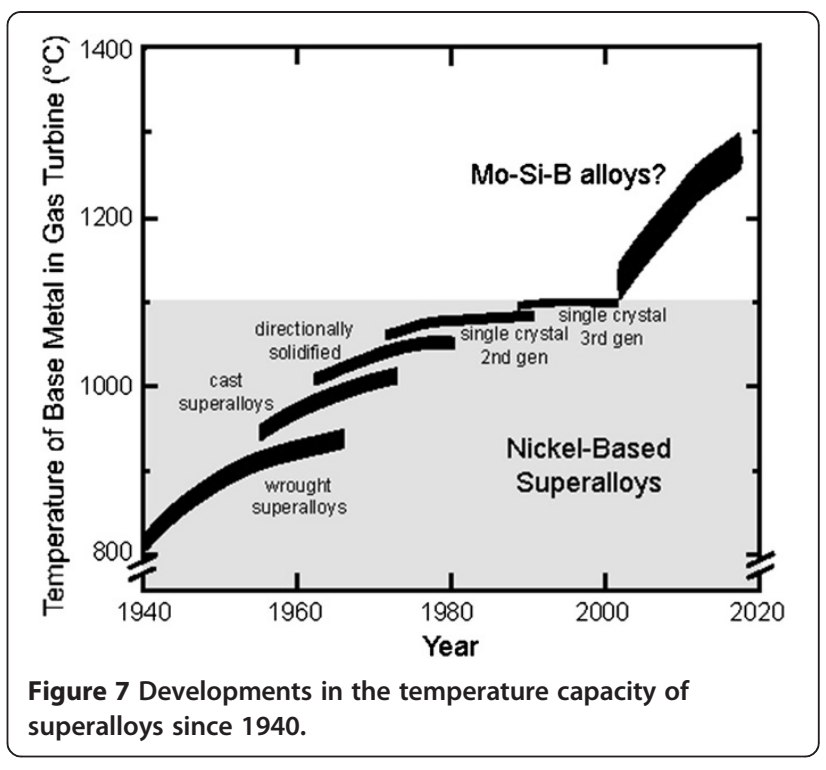

contributes efficiently to the continuous performance increase of GT engines in terms of power and thermal efficiency. Recently, a new SC Ni-based superalloy has been jointly developed by the Kansai Electric Power Company Co., Inc. (KEPCO), Nagoya University, and Hitachi Ltd., Japan (Kansai Electric Power Company (KEPCO) 2011). This SC superalloy contains $\mathrm{Ni}, \mathrm{Co}, \mathrm{Cr}, \mathrm{W}, \mathrm{Al}, \mathrm{Ti}, \mathrm{Ta}, \mathrm{Re}$, $\mathrm{Hf}$, etc., and its microstructure is shown in Figure 8.

The cubical morphology of gamma-prime $\left(\gamma^{\prime}\right)$ precipitates in the gamma $(\gamma)$ matrix of the SC superalloy (see Figure 8) indicates its high-temperature creep strength which is also confirmed by the temperature capability $\left(>1,500^{\circ} \mathrm{C}\right)$ of this superalloy (Kansai Electric Power Company (KEPCO) 2011)

The chemical compositions of three SC blade superalloys (AM1, René N6, and MC-534) are reported in Table 2. An interesting common feature of all the three $\mathrm{SC}$ alloys is their high $\mathrm{W}, \mathrm{Al}$, and Ta contents. A unique feature of the $\mathrm{SC}$ superalloy MC-534 is its considerable $\mathrm{Re}$ and $\mathrm{Ru}$ contents which impart remarkable creep resistance to the alloy (see Figure 9). Figure 9 compares tensile creep behaviors of the three SC superalloys (AM1, René N6, and MC-534) at $760^{\circ} \mathrm{C} / 840 \mathrm{MPa}$; all the three alloy specimens were tested at orientations within $5^{\circ}$ of a $<001>$ direction (Diologent and Caron 2004).

It is clearly evident from the creep curves in Figure 9 that the SC superalloy MC-534 has the lowest creep strain or deformation as compared to the other two SC alloys, which is attributed to the former's considerable $\mathrm{Re}$ and $\mathrm{Ru}$ contents (see Table 2). However, the creep rupture life of AM1 has been reported to be ten times longer than that of MC-534. Additionally, the excellent tensile yield strength at $700^{\circ} \mathrm{C}$ of the SC superalloy AM1 as compared to other competitive GT-blade superalloys is remarkable (see Table 3) (Sajjadi and Zebarjad 2006; Kennedy 2005). 
Table 2 Chemical composition of typical GT-blade superalloys

\begin{tabular}{|c|c|c|c|c|c|c|c|c|c|c|c|c|c|c|c|}
\hline Superalloy & $\% \mathrm{Cr}$ & $\%$ Co & $\% \mathrm{Ti}$ & $\% W$ & $\% A I$ & $\%$ Ta & \%Мo & $\% \mathrm{Fe}$ & $\% C$ & $\% \mathrm{~B}$ & $\% \mathrm{Nb}$ & $\% \operatorname{Re}$ & $\%$ Ru & $\% \mathrm{Hf}$ & $\% \mathrm{Ni}$ \\
\hline SC: AM1 & 7.8 & 6.5 & 1.1 & 5.7 & 5.2 & 7.9 & 2 & - & - & - & - & - & - & - & Balance \\
\hline SC: René N6 & 4.5 & 12 & - & 5.7 & 6 & 7.5 & 1.1 & - & 0.05 & 0.04 & - & 5.3 & - & 0.15 & Balance \\
\hline MC-534 & 4 & - & - & 5 & 5.8 & 6 & 4 & - & - & - & - & 3 & 4 & 0.1 & Balance \\
\hline GTD-111 & 13.5 & 9.5 & 4.75 & 3.8 & 3.3 & 2.7 & 1.53 & 0.23 & 0.09 & 0.01 & - & - & - & - & Balance \\
\hline Allvac ${ }^{\oplus} 718$ Plus & 17.9 & 9 & 0.74 & 1.04 & 1.5 & - & 2.68 & 9.3 & 0.02 & 0.003 & 5.51 & - & - & - & Balance \\
\hline
\end{tabular}

The GTD-111 superalloy The GTD-111 superalloy is employed in manufacturing of the first-stage blades of highpower gas turbines. The chemical composition of GTD-111 superalloy is presented in Table 2 which shows a high aluminum and titanium contents to ensure precipitation of high volume fraction of the $\gamma^{\prime}$ particles in the microstructure for good creep strength.

The GTD-111 superalloy has a multiphase structure consisting of $\gamma$ matrix, $\gamma^{\prime}$ precipitate, carbide, $\gamma-\gamma^{\prime}$ eutectic, and a small amount of deleterious phases such as $\delta, \eta, \sigma$, and Laves (Sajjadi and Nategh 2001; Sajjadi et al. 2002). The superalloy maintains fairly good tensile yield strength of $780 \mathrm{MPa}$ with $10 \%$ elongation at $700^{\circ} \mathrm{C}$ (see Table 3) (Sajjadi and Zebarjad 2006). The alloy obtains its hightemperature creep strength mainly through $\gamma^{\prime}$ precipitates that are present with $>60 \%$ volume fraction. The primary $\gamma^{\prime}$ particles have a cubic shape with $0.8-\mu \mathrm{m}$ average edge. The fine spherical $\gamma^{\prime}$ particles precipitated during an aging

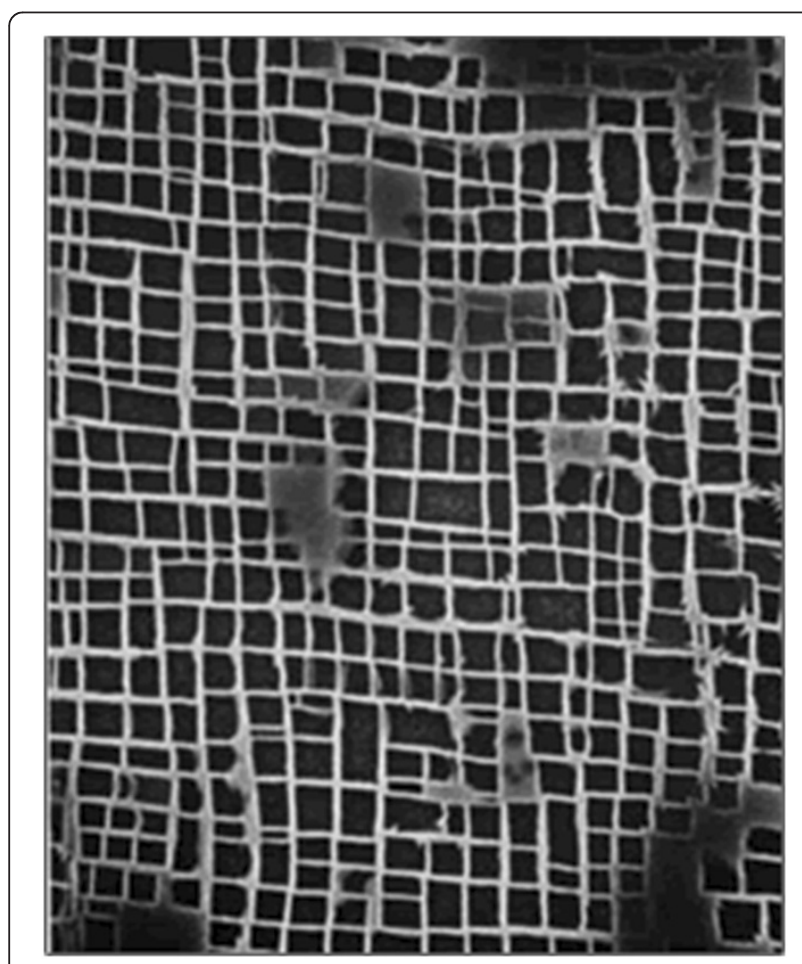

Figure 8 Microstructure of a recently developed SC superalloy (Kansai Electric Power Company (KEPCO) 2011). treatment have an average diameter of $\approx 0.1 \mu \mathrm{m}$. The serrated grain boundaries increase creep life and creep plasticity. Figure 10 shows the as-standard heat-treated microstructure of GTD-111 (Sajjadi et al. 2006).

The Allvac ${ }^{\oplus}$ 718Plus ${ }^{\mathrm{Tn}}$ superalloy Recently, a new 718Plus nickel-base superalloy has been developed for application in energy-efficient gas-turbine engines, thereby allowing a considerable increase in TIT for higher power output. The Allvac ${ }^{\oplus} 718$ Plus $^{\mathrm{TM}}$ is a novel nickel-based superalloy, which has been designed for heavy-duty applications in aerospace and industrial gas turbines (Zickler et al. 2009).

The Allvac ${ }^{\oplus} 718$ Plus $^{\text {Ts }}$ alloy contains nanometer-sized spherical $\gamma^{\prime}$ phase precipitates $\left(\mathrm{Ni}_{3}(\mathrm{Al}, \mathrm{Ti})\right)$ and plate-shaped $\delta$ phase precipitates $\left(\mathrm{Ni}_{3} \mathrm{Nb}\right)$ of micrometer size. The chemical composition of the Allvac ${ }^{\circ} 718$ Plus $^{\text {TM }}$ superalloy is shown in Table 2 which shows higher $\mathrm{Cr}$ and Mo as compared to the GTD superalloy. An exceptional feature in the composition of the Allvac ${ }^{\odot} 718$ Plus $^{\text {TM }}$ alloy is its high niobium content (which is absent in the GTD alloy). The high niobium content restricts the coarsening of the $\gamma^{\prime}$ particles in the microstructure of the superalloy, thereby ensuring long-time creep resistance so as to allow operation of the GT engine at high temperature for longer periods of time (Huda 2009; Reed 2006).

The transmission electron micrograph of the Allvac ${ }^{\circ}$ 718 Plus $^{\mathrm{TM}}$ superalloy, after aging at $1,148 \mathrm{~K}$ for $7,800 \mathrm{~s}$, shows spherical precipitates of $\gamma^{\prime}$ phase in the $\gamma$ matrix (see Figure 11). The aging heat treatments of the superalloy lead to a significant increase of hardness, which is due to

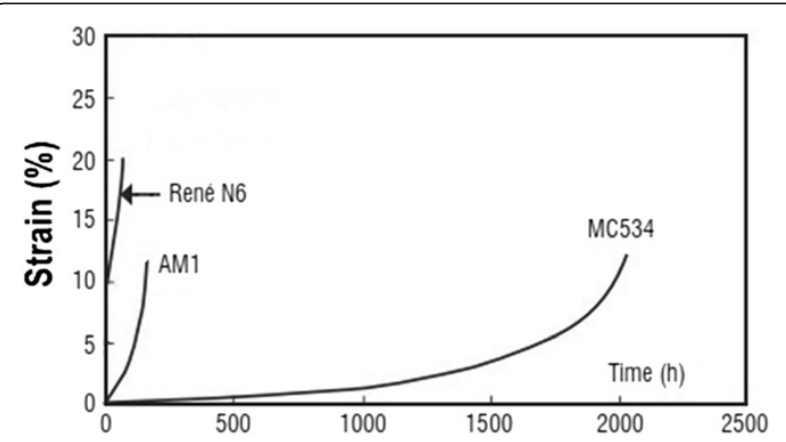

Figure 9 Creep curves at $760^{\circ} \mathrm{C} / 840 \mathrm{MPa}$ for three typical $<001>$ SC superalloys. 
Table 3 Tensile yield strength at $700^{\circ} \mathrm{C}$ for three typical GT-blade superalloys

\begin{tabular}{llll}
\hline Superalloy & SC superalloy: AM1 & GTD-111 & Allvac $^{\oplus}$ 718Plus \\
\hline Yield strength & $1,550 \mathrm{MPa}$ & $780 \mathrm{MPa}$ & $1,014 \mathrm{MPa}$ \\
\hline
\end{tabular}

precipitation of intermetallic phases (Zickler et al. 2009). The tensile properties at $700^{\circ} \mathrm{C}$ for the superalloy have been reported to be very good i.e., $\sigma_{\mathrm{y}}=1,014 \mathrm{MPa}$ and $\%$ elongation $=25$ (see Table 3$)$ (Kennedy 2005).

\section{Improving GT efficiency through thermal barrier coatings $T B C$ and coating technologies}

A TBC is a multilayer coating system that consists of an insulating ceramic outer layer (top coat) and a metallic inner layer (bond coat) between the ceramic and the substrate. The function of the ceramic top coat is to insulate the metallic substrate from high surface temperature, thereby lowering the component's temperature and reducing the oxidation and hot corrosion of bond coatings while simultaneously reducing cyclic thermal strains (Gurrappa and Sambasiva 2006). Recently, Kitazawa et al. (2010) have reported that a temperature gradient of $150^{\circ} \mathrm{C}$ can be achieved by using a ceramic $\mathrm{TBC}\left(\mathrm{Y}_{2} \mathrm{O}_{3}-\mathrm{ZrO}_{2}\right.$ top coat $)$ on superalloy components. In most cases, the top coat and bond coats are applied by plasma spraying; however, sputtering and electron beam physical vapor deposition (EBPVD) are also used. The commonly used method of thermal spraying of TBCs on developed metal surfaces involves a metallic bond coating either by cold spraying (CS) or by low-pressure plasma spraying (LPPS) followed by deposition of a ceramic top coat by either air plasma spraying (APS) or EBPVD.

The following techniques have been developed in recent years: (a) EBPVD and (b) electrophoretic deposition (EPD). These techniques are discussed in 'Electron beam physical vapor deposition' and 'Electrophoretic deposition' subsections, respectively.

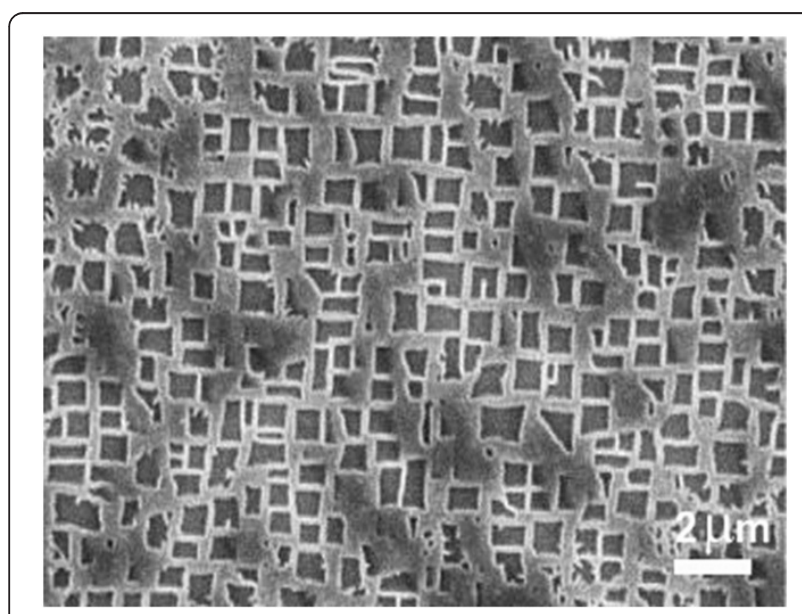

Figure 10 SEM micrograph showing primary $\gamma^{\prime}$ in as heat-treated GTD-111 superalloy (Sajjadi et al. 2006).

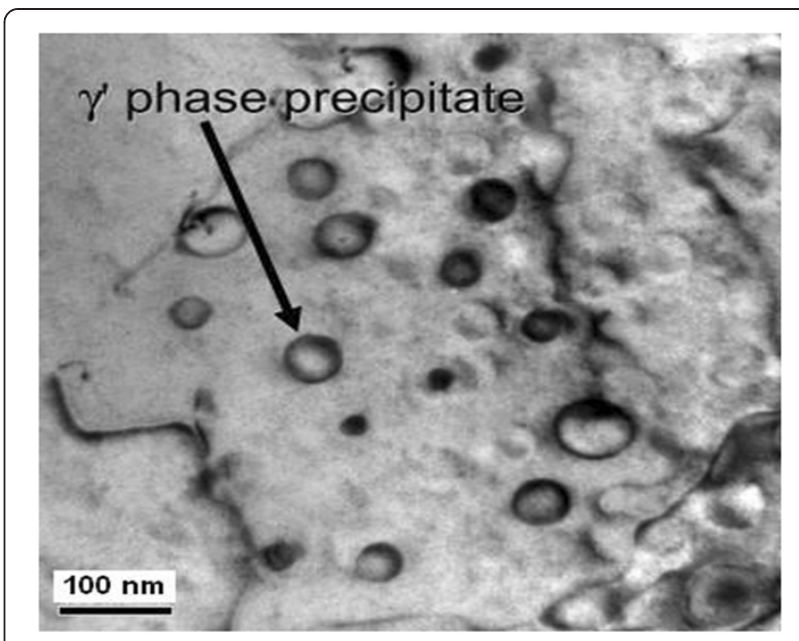

Figure 11 TEM image of superalloy ATI Allvac ${ }^{\circledR} 718 \mathrm{Plus}^{\mathrm{TM}}$ after aging at $1,148 \mathrm{~K}$ for $7,800 \mathrm{~s}$ (Zickler et al. 2009).

The failure of a TBC system can occur by three modes: (a) de-bonding, (b) de-cohesion, and (c) mechanical disruption. Failure by de-bonding occurs due to de-bonding along the interface between the bond coating and the thermally grown protective oxide (TGO), predominantly along the $\alpha-\mathrm{Al}_{2} \mathrm{O}_{3}$ layer which bonds to the zirconia. The coating failure by de-cohesion occurs as a result of de-cohesion of the ceramic layer (near the interface) with the TGO. Mechanical disruption (rumpling) of bond coatings usually leads to significant displacement of the bond coating of the TGO and TGO-ceramic interfaces causing failure of the TBC. Tramp elements such as $\mathrm{S}$ have been shown to be detrimental to TGO adherence, so that alloying practices have been developed that routinely achieve $\mathrm{S}$ levels as low as 1 $\mathrm{ppm}$. Controlled additions of reactive elements such as $\mathrm{Y}$ and $\mathrm{Hf}$ also can be used to counter the effects of S; such additions have been also shown significantly to modify the growth mechanism of the TGO and reduce its rate of growth, which promises to extend TBC lifetimes (Pint et al. 1998). Overall, improvements in understanding of the mechanisms of TBC degradation are providing routes for further improvements in their durability (Wright and Gibbons 2007). There has been a significant interest in the development of thermally grown oxides (TGO) in a deposited overlay (Choi et al. 2010). The integrity of the coating will depend on the ability of the alloy to grow an oxide layer with an appropriate combination of properties. While this approach can reduce costs and weight, it has been suggested that the life of a TBC system can be improved when the bond coating is eliminated because the TGO formed on the substrate benefits from the strength of the underlying alloy and, thus, has a greater resistance to buckling during thermal cycling (Wright and Gibbons 2007; Walston 2004).

The limited lifetime of the TBC system forms the boundary of this 40-year-old concept (Troczynski et al. 
1996). Until today, the use of TBCs on aircraft turbine blades is not design-integrated: they are used frequently to lower the metal temperature and therefore elongate the lifetime of a blade itself. If the coating spalls off, the metal temperature will increase but not above a critical point. For design-integrated TBCs with improvement of efficiency, fuel consumption, and exhaust pollution, $100 \%$ reliability is necessary (Stöver and Funke 1999).

\section{Electron beam physical vapor deposition}

The EBPVD TBCs consist of thin ceramic layers of low thermal conductivity - typically, partially stabilized zirconia (PSZ) that are usually applied on GT components' surfaces having a metallic corrosion-resistant coating (DeMasi-Marcinand and Gupta 1994). During EBPVD, a high-energy EB melts and evaporates a ceramic-source ingot in a vacuum chamber. The ingot is not the only ceramic source; there are also possibilities to deposit ceramics with powder. Preheated substrates are positioned in the vapor cloud above where the vapor is deposited on substrates at deposition rates of 0.1 to $0.25 \mathrm{~mm} / \mathrm{s}$ (Movchan 1996). Typical columnar microstructures and aerodynamically smooth surfaces are obtained without the need for final polishing or conditioning of cooling holes. Due to the columnar microstructure, the lifetime of the TBC is prolonged and the damage tolerance improved. The application of the TBCs increases the engine performance by either increasing the gas-turbine inlet temperature or reducing the required cooling air flow (Schulz et al. 1997).

\section{Electrophoretic deposition}

An alternative, relatively inexpensive way to apply an oxide TBC is by EPD. Figure 12 illustrates a typical coating system in a high-pressure turbine blade (Padture et al. 2002).

In recent years, EPD technique has been widely used for TBC (Boccaccini and Zhitomirsky 2002; Boccaccini et al. 2006; Besra and Liu 2007; Corni et al. 2008). For EPD, a suspension is prepared from particles of the desired material in a dispersing liquid. The suspension can be stabilized by electrical charge on the surface of the particles due to the acid or alkaline nature of the suspension or by charges due to adsorption of a surfactant. Steric hindrance can be used as well, but the particles do need a surface charge for the process to work (Dusoulier et al. 2011).

When an electrical field is applied over the suspension, the charged particles move toward the oppositely charged electrode where they form a deposit. Upon drying and heat treatment (sintering), this is the product, either freestanding or on a substrate.

For corrosion protection, it is essential that the coating covers the substrate completely and that the coating does not contain porosity. Studies on EPD have shown that EPD using water as a dispersant liquid leads to gas evolution at the electrodes and that entrapped gasses lead to porosity in the product (Doungdaw et al. 2005). For conducting EPD, it is usual to first prepare a suspension in an organic liquid such as ethanol, propanol, or isobutanol. Since organic liquids have a lower dielectric constant than water, care must be taken to select a system that provides adequate surface charge to the particles. Even so, it is most likely necessary to use a voltage of 100 to $300 \mathrm{~V}$ between the electrodes (Mohanty et al. 2008).

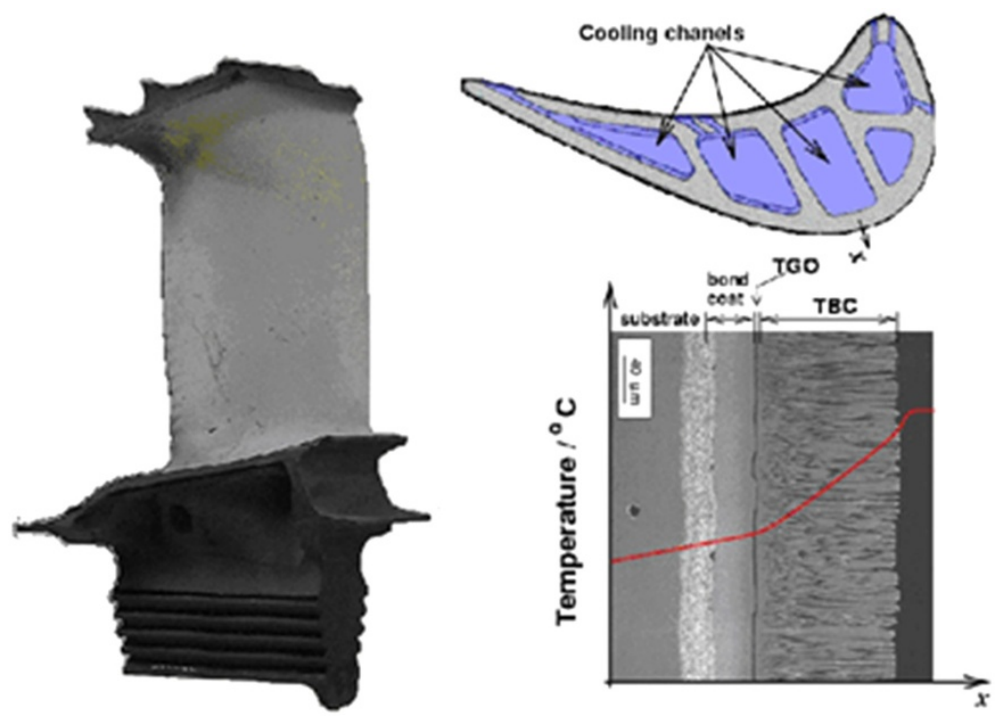

Figure 12 A typical coating system in a high-pressure turbine blade. Clockwise, a TBC-coated high-pressure turbine blade, with view from the top showing the cooling systems, and schematic profile temperature; note the drop of temperature close to the blade surface due to the presence of a thin cooling air film (Boccaccini and Zhitomirsky 2002). 
To accommodate stresses due to a thermal expansion mismatch between substrate and coating, it is desirable that there is a gradient of properties, rather than a sharp interface. This can be achieved by applying a Ni-rich coating close to the surface and increasing the amount of alumina during deposition. Such functionally graded materials (FGMs), consisting of alumina and zirconia, have been produced by EPD (Put et al. 2003). FGMs can be deposited if two separate suspensions of the components are made and mixed at an appropriate rate while the deposition is in progress.

A new chart for GT researchers, designers, and manufacturers Having reviewed the latest energy-efficiency techniques and recent advancements in superalloys and coatings, a new robust chart is now developed. It is evident from Table 4 that GT designer/manufacturers must take into

Table 4 Chart for enhancing power output and profitability in industrial GTs

\begin{tabular}{|c|c|c|c|c|}
\hline $\begin{array}{l}\text { Approach to improve } \\
\text { thermal efficiency }\end{array}$ & $\begin{array}{l}\text { Design features required } \\
\text { in GT system }\end{array}$ & Additional benefit & Reference in text/figure/table & Citation \\
\hline Intercooling & $\begin{array}{l}\text { Pass the working fluid } \\
\text { through a 1st stage } \\
\text { compressor, then a cooler, } \\
\text { followed by a 2nd stage } \\
\text { compressor }\end{array}$ & $\begin{array}{l}\text { An increase in the } \\
\text { maximum feasible } \\
\text { pressure ratio }\end{array}$ & 'Intercooling' section & Carapellucci 2009 \\
\hline \multirow[t]{2}{*}{ Regeneration } & \multirow{2}{*}{$\begin{array}{l}\text { Pass the still-warm post- } \\
\text { turbine fluid through a heat } \\
\text { exchanger to pre-heat the } \\
\text { fluid just entering the } \\
\text { combustion chamber }\end{array}$} & $\begin{array}{l}\text { Offsets fuel } \\
\text { consumption }\end{array}$ & \multirow[t]{2}{*}{ 'Regeneration' section } & \multirow[t]{2}{*}{ Bassily 2008} \\
\hline & & $\begin{array}{l}\text { Less power loss as } \\
\text { waste heat }\end{array}$ & & \\
\hline Combined cycle (CC) & $\begin{array}{l}\text { Combine Brayton engine } \\
\text { with Rankine engine to } \\
\text { obtain gas-steam CC }\end{array}$ & $\begin{array}{l}\text { Thermal efficiency as } \\
\text { high as } 60 \%\end{array}$ & 'Combined cycle' section & $\begin{array}{l}\text { Gorji-Bandpy et al. 2010; } \\
\text { Canière et al. 2006; Najjar } 2001\end{array}$ \\
\hline \multirow[t]{3}{*}{ Cogeneration } & $\begin{array}{l}\text { Couple natural gas turbine } \\
\text { with electrical generator }\end{array}$ & \multirow{3}{*}{$\begin{array}{l}\text { Steam obtained may } \\
\text { be used for hot-water } \\
\text { production or space } \\
\text { heating }\end{array}$} & \multirow[t]{3}{*}{ 'Cogeneration' section, Figure 1} & \multirow[t]{3}{*}{$\begin{array}{l}\text { Najjar et al. 2004; Brooks 2000; } \\
\text { Agarwal et al. 2011; Pilavachi } 2000\end{array}$} \\
\hline & $\begin{array}{l}\text { Direct exhaust heat from } \\
\text { the GT to WHRB }\end{array}$ & & & \\
\hline & $\begin{array}{l}\text { Direct steam from WHRB to } \\
\text { a steam turbine generator }\end{array}$ & & & \\
\hline \multirow[t]{3}{*}{ IAC and STIG cycles } & $\begin{array}{l}\text { Cool the air before } \\
\text { compression }\end{array}$ & $\begin{array}{l}\text { Higher power output } \\
\text { in peak summer } \\
\text { demands }\end{array}$ & \multirow[t]{3}{*}{$\begin{array}{l}\text { 'Inlet air cooling and STIG cycles' } \\
\text { section Figures } 3 \text { and } 4\end{array}$} & \multirow[t]{3}{*}{ Brooks 2000; Al-Ansary 2007} \\
\hline & $\begin{array}{l}\text { Use the new economic } \\
\text { system: ejector refrigeration } \\
\text { system to cool turbine inlet } \\
\text { air }\end{array}$ & $\begin{array}{l}\text { Low power } \\
\text { consumption by } \\
\text { using ejector } \\
\text { refrigeration system }\end{array}$ & & \\
\hline & $\begin{array}{l}\text { Add steam to the } \\
\text { combustion chamber }\end{array}$ & & & \\
\hline \multirow[t]{2}{*}{ Higher TIT } & $\begin{array}{l}\text { Use advanced/SC } \\
\text { superalloy in turbine } \\
\text { components }\end{array}$ & $\begin{array}{l}\text { Higher revenue/ } \\
\text { profitability }\end{array}$ & \multirow{2}{*}{$\begin{array}{l}\text { 'Higher turbine inlet temperature,' } \\
\text { 'Enhancing profitability in power } \\
\text { generation,' and 'Improving GT } \\
\text { efficiency through advanced } \\
\text { superalloys' sections; } \\
\text { Figures } 5,6,7,8,9,10,11,12 \text {; } \\
\text { Equations } 3 \text { and } 4\end{array}$} & \multirow[b]{2}{*}{$\begin{array}{l}\text { Nye Thermodynamics Corporation } \\
\text { (NTC) 2011; Zeren 1982; Schulz et al. } \\
\text { 2008; Braue et al. 2007; Huda et al. } \\
\text { 2011; Jianting 2011; Cao and Loria } \\
\text { 2005; Sajjadi and Nategh 2001; } \\
\text { Sajjadi et al. 2002; Sajjadi et al. 2006; } \\
\text { Zickler et al. 2009; Perepezko 2009; } \\
\text { Todd 1989; Kansai Electric Power } \\
\text { Company (KEPCO) 2011; Diologent } \\
\text { and Caron 2004; Sajjadi and } \\
\text { Zebarjad 2006; Kennedy 2005; } \\
\text { Kitazawa et al. 2010; Pint et al. 1998; } \\
\text { Wright and Gibbons 2007; Choi et al. } \\
\text { 2010; Walston 2004; Troczynski et al. } \\
\text { 1996; DeMasi-Marcinand and Gupta } \\
\text { 1994; Movchan 1996; Schulz et al. } \\
\text { 1997; Padture et al. 2002; Boccaccini } \\
\text { and Zhitomirsky 2002; Boccaccini } \\
\text { et al. 2006; Besra and Liu 2007; Corni } \\
\text { et al. 2008; Dusoulier et al. 2011; } \\
\text { Doungdaw et al. 2005; Mohanty } \\
\text { et al. 2008; Put et al. 2003 }\end{array}$} \\
\hline & Use TBC using EPD/EBPVD & $\begin{array}{l}\text { MHI, J-series engine } \\
\text { operating at } \\
\text { TIT }=1,600^{\circ} \mathrm{C} \text { has } \\
\text { achieved efficiency } \\
\text { exceeding } 60 \%\end{array}$ & & \\
\hline
\end{tabular}


consideration a number of mechanical and materials aspects for enhancing power output and profitability in today's industrial GTs.

\section{Conclusions}

It is concluded that in order to enhance power output and profitability, the latest efficiency-improvement technologies and advanced superalloys and TBCs should be integrated into the industrial GT systems. In countries with hot summers, it is recommended to adopt IAC by use of Ejector Refrigeration Systems technology. In simple turbines, it is recommended to retrofit simple cycle with IAC and STIG technologies for boosting power output from 30 to 48.25 MW and to improve generation efficiency from $29.9 \%$ to $33.4 \%$. In view of the latest development in the GT technology, which enables them to be operated at $\mathrm{TIT}=1,600^{\circ} \mathrm{C}$, it is recommended to develop superalloys based on highermelting temperatures (such as Mo-base superalloys). In such advanced GT engines with efficiencies exceeding 60\%, it is strongly recommended to use CCGT applying SC superalloys and TBC as well as closed-loop steam cooling. In TBC practice, it is recommended to first apply a Ni-rich coating close to the surface and then increasing the amounts of FGMs, alumina and zirconia, during EPD/ EBPVD, for achieving the best results. Finally, a new chart for increasing power output has been presented, which would enable GT designers to manufacture GT engines with enhanced profitability.

\section{Abbreviations \\ CCGT: combined cycle gas turbine; EBPVD: electron beam physical vapor deposition; EPD: electrophoretic deposition; FGM: functionally graded material; GE: General Electric; GT: gas turbine; H-turbine: horizontal turbine; IAC: inlet air cooling; kW: kilowatts; kW h: kilowatt hour; Qin: input heat energy; SC: single crystal; STIG: steam injection gas; TBC: thermal barrier coating; Tcold: temperature of the heat removed; TGO: thermally grown oxide; Thot: temperature of the heat addition; TIT: turbine inlet temperature; WHRB: waste heat recovery boiler; Wout: effective work done.}

\section{Competing interest}

The authors declare that they have no competing interests.

\section{Authors' contributions}

$\mathrm{ZH}$ initiated the idea and drafted $80 \%$ of the manuscript. He was the project leader. TZ contributed to drawing diagrams, particularly, Figure 5, Fig 6, and Fig 9. She also contributed to 'Introduction/Review". HAA provided illustrated 'Ejector refrigeration system (Fig 4)'. He also contributed in explaining IAC by using ejector refrigerator system. All authors read and approved the final manuscript.

\section{Acknowledgements}

The authors (ZH and TZ) are grateful to the I.P.P.P, University of Malaya, Malaysia and the Ministry of Science, Technology, and Innovation (MOSTI), Government of Malaysia for the research grant No. 03-01-03-SF0477 awarded during 2009 to support the work reported in the paper.

\section{Author details}

${ }^{1}$ Department of Engineering (Mechanical Engineering Program), Nilai University, Nilai, Negeri Sembilan 71800, Malaysia. ${ }^{2}$ Department of Mechanical Engineering, University of Malaya, Kuala Lumpur 50603, Malaysia. ${ }^{3}$ Department of Mechanical Engineering, King Saud University, P.O. Box 800, Riyadh 11421, Saudi Arabia.
Received: 14 February 2014 Accepted: 13 May 2014

Published online: 07 August 2014

\section{References}

Agarwal, S, Kachhwaha, SS, \& Mishra, RS. (2011). Performance improvement of a simple gas turbine cycle through integration of inlet air evaporative cooling and steam injection. Journal of Scientific \& Industrial Research, 70(7), 544-553.

Al-Ansary, HA. (2007). The use of ejector refrigeration systems for turbine inlet air cooling-a thermodynamic and CFD study. Long Beach, California: In Proceedings of Energy Sustainability Conference 2007. Paper No. ES2007-36044.

Balat, M. (2010). Greenhouse gas emissions and reduction strategies of the European Union. Energy Sources, Part B: Economics, Planning and Policy, 5(2), 165-177.

Bassily, AM. (2008). Enhancing the efficiency and power of the triple-pressure reheat combined cycle by means of gas reheat, gas recuperation, and reduction of the irreversibility in the heat recovery steam generator. Applied Energy, 85(12), 1141-1162.

Besra, L, \& Liu, M. (2007). A review of fundamentals and applications of electrophoretic deposition (EPD). Progress in Materials Science, 52, 1-61.

Boccaccini, AR, Roether, JA, Thomas, BJC, Shaffer, MSP, Chavez, E, Stoll, E, \& Minay, EJ. (2006). The electrophoretic deposition of inorganic nanoscaled materials-a review. Journal of the Ceramic Society of Japan, 114(1), 1-14.

Boccaccini, RA, \& Zhitomirsky, I. (2002). Application of electrophoretic and electrolytic deposition techniques in ceramics processing. Current Opinion in Solid State and Materials Science, 6, 251-260.

Boyce, MP. (1982). Gas turbine engineering handbook. Gulf Professional. ISBN/ASIN: 0884157326.

Braue, W, Mechnich, P, Fritscher, K, \& Niewolak, L. (2007). Compatibility of mixed zone constituents ( $\left.Y A G, Y A P, Y C_{3}\right)_{3}$ ) with a chromia-enriched TGO phase during the late stage of TBC lifetime. Surface \& Coatings Technology, 202(4-7), 670-675.

Brooks, FJ. (2000). GE gas turbine performance characteristics, GER-3567H.

Canière, H, Willockx, A, Dick, E, \& De Paepe, M. (2006). Raising cycle efficiency by intercooling in air-cooled gas turbines. Applied Thermal Engineering, 26(16), 1780-1787.

Cao, W-D, \& Loria, EA (Eds.). (2005). Superalloys 718, 625, 706 and derivatives (pp. 165-177). Warrendale: The Minerals Metals \& Materials Society.

Carapellucci, R. (2009). A unified approach to assess performance of different techniques for recovering exhaust heat from gas turbines. Energy Conversion and Management, 50(5), 1218-1226.

Choi, HJ, Jedlinski, J, Yao, B, \& Sohn, YH. (2010). Development of Thermally Grown Oxide on $\beta$-NiAl During Initial Stages of Oxidation at $1100^{\circ} \mathrm{C}$. Surface and Coatings Technology, 205, 1206-1210.

Corni, I, Ryan, MP, \& Boccaccini, AR. (2008). Electrophoretic deposition: from traditional ceramics to nanotechnology. Journal of the European Ceramic Society, 28, 1353-1367.

De Biasi, V. (2002). M701G2 combined cycle is rated at 489 MW and $58.7 \%$ efficiency. Gas Turbine World, 7, 9-13.

DeMasi-Marcinand, JY, \& Gupta, DK. (1994). Protective coatings in the gas turbine engine. Surface \& Coatings Technology, 68(69), 1-9.

Diologent, F, \& Caron, P. (2004). On the creep behavior at $1033 \mathrm{~K}$ of new generation single-crystal superalloys. Materials Science and Engineering A, 385(1-2), 245-257.

Doungdaw, S, Uchikoshi, T, Noguchi, Y, Eamchotchawalit, C, \& Sakka, Y. (2005). Electrophoretic deposition of lead zirconate titanate (PZT) powder from ethanol suspension prepared with phosphate ester. Science and Technology of Advanced Materials, 6, 927-932.

Dusoulier, L, Cloots, R, Vertruyen, B, Moreno, R, Burgos-Montes, O, \& Ferrari, B. (2011). YBa2Cu3O7- $x$ dispersion in iodine acetone for electrophoretic deposition: surface charging mechanism in a halogenated organic media. Journal of the European Ceramic Society, 31, 1075-1086.

Gorji-Bandpy, M, Goodarzian, H, \& Biglari, M. (2010). The cost-effective analysis of a gas turbine power plant. Energy Sources, Part B: Economics, Planning and Policy, 5(4), 348-358.

Gurrappa, l, \& Sambasiva, RA. (2006). Thermal barrier coatings for enhanced efficiency of gas turbine engines. Surface \& Coatings Technology, 201, 3016-3029.

Huda, Z. (1995). Development of design principles for a creep-limited alloy for turbine blades. Journal of Materials Engineering and Performance, 4(1), 48-53.

Huda, Z. (2007). Development of heat treatment process for a P/M superalloy for turbine blades. Materials and Design, 28(5), 1664-1667.

Huda, Z. (2009). Metallurgical failure analysis for a blade failed in a gas-turbine engine of a power plant. Materials and Design, 30, 3121-3125.

Huda, Z, Zaharinie, T, \& Islam, SH. (2011). Effects of annealing parameters on grain growth behavior of Haynes 718 superalloy. International Journal of the Physical Sciences, 6(30), 7073-707. 
Jianting, G. (2011). The current situation of the application and development of superalloys in the field of energy industry. Acta Metallurgica Sinica, 46(5), 513-527.

Kansai Electric Power Company (KEPCO). (2011). Development of Ni-base SC superalloys for power generation gas turbines. In http://www.kepco.co.jp/ english/rd/topics/topics_3.html. Accessed 8 December 2011.

Kennedy, RL. (2005). ALLVAC ${ }^{\oplus 18 P L U S}{ }^{\mathrm{Tm}}$, superalloy for the next forty years. In EA Loria (Ed.), Superalloys 718, 625, 706 and derivatives 2005. TMS (The Minerals, Metals \& Materials Society), Warrendale, PA 15086-7514 USA.

Kitazawa, R, Tanaka, M, Kagawa, Y, \& Liu, YF. (2010). Damage evolution of TBC system under in-phase thermo-mechanical tests. Materials Science and Engineering $B$ 173(1-3), 130-134

Kuchling, H. (1980). Physik. Leipzig: VEB. pp. 82, 124, 189-190.

Larson, ED, \& Marrison, Cl. (1997). Economic scales for first-generation biomassgasifier/gas turbine combined cycles fueled from energy plantations. Jorunal of Engineering for Gas Turbines and Power - Trans of the ASME, 119(2), 285-291.

Mahlia, TMI. (2002). Emissions from electricity generation in Malaysia. Renewable Energy, 27(2), 293-300.

Martin, U, Jerenz, M, Mühle, U, \& Oettel, H. (2001). Microstructure and modeling of the high temperature deformation behavior of TBC-coated superalloys. Materials Science and Engineering A, 319-321, 388-392.

Miller, ME, \& Chambers, WL. (1987). "Gas Turbine Design and Superalloys". In CT Sims, NS Stoloff, \& WC Hagel (Eds.), Superalloys II. USA: Wiley.

Mohanty, G, Laxmidhar, B, Sarama, B, \& Singh, BP. (2008). Optimization of electrophoretic deposition of alumina onto steel substrates from its suspension in isopropanol using statistical design of experiments. Materials Research Bulletin, 43, 1814-1828.

Movchan, BA. (1996). EB-PVD technology in the gas turbine industry: present and future. Journal of Metals, 48(11), 40-45.

Najjar, YSH. (2001). Efficient use of energy by utilizing gas turbine combined systems. Applied Thermal Engineering, 21, 407-438.

Najjar, YSH, Alghamdi, AS, \& Al-Beirutty, MH. (2004). Comparative performance of combined gas turbine systems under three different blade cooling schemes. Applied Thermal Engineering, 24(13), 1919-1934.

Najjar, YSH, \& Zaamout, MS. (1996). Performance analysis of gas turbine air-bottoming combined system. Energy Conversion and Management, 37(4), 399-403.

Nye Thermodynamics Corporation (NTC). (2011). Gas turbine prices \$ per KW. In http://www.gas-turbines.com/trader/kwprice.htm. Accessed 8 December 2011.

Padture, NP, Gell, M, Jordan, EH. (2002). Thermal barrier coatings for gas-turbine engine applications. Science, 296, 280-284.

Perepezko, JH. (2009). The hotter the engine, the better. Science, 326(5956), 1068-1069.

Pilavachi, PA. (2000). Power generation with gas turbine systems and combined heat and power. Applied Thermal Engineering, 20, 1421-1429.

Pint, BA, Wright, IG, Lee, WY, Zhang, Y, Prüssner, K, \& Alexander, KB. (1998). Substrate and bond coat compositions: factors affecting alumina scale adhesion. Materials Science and Engineering A, 245(2), 201-211.

Put, S, Vleugels, J, Anne, G, \& Van der Biest, O. (2003). Functionally graded ceramic and ceramic metal composites shaped by electrophoretic deposition. Colloids and Surfaces A: Physicochemical and Engineering Aspects, 222, 223-232.

Reed, RC. (2006). The superalloys: fundamentals and applications. UK: Cambridge University Press.

Sajjadi, SA, \& Nategh, S. (2001). A high temperature deformation mechanism map for the high performance Ni-base superalloy GTD-111. Materials Science and Engineering A, 307(1-2), 158-164.

Sajjadi, SA, Nategh, S, \& Guthrie, RIL. (2002). Study of microstructure and mechanical properties of high performance Ni-base superalloy GTD-111. Materials Science and Engineering A, 325, 484-489.

Sajjadi, SA, \& Zebarjad, SM. (2006). Study of fracture mechanism of a nickel-base superalloy at different temperatures. Journal of Achievements in Materials and Manufacturing Engineering, 18(1-2), 227-230.

Sajjadi, SA, Zebarjad, SM, Guthrie, RIL, \& Isac, M. (2006). Microstructure evolution of high-performance Ni-base superalloy GTD-111 with heat treatment parameters. Journal of Materials Processing Technology, 175(1-3), 376-381.

Schulz, U, Fritscher, K, Leyens, C, Peters, M, \& Kaysser, WA. (1997). The thermocyclic behavior of differently stabilized and structured EB-PVD TBCs. Journal of Materials, 49(10), http://onlinelibrary.wiley.com/doi/10.1002/mawe.19970280811/abstract.

Schulz, U, Fritscher, K, \& Ebach-Stahl, A. (2008). Cyclic behavior of EB-PVD thermal barrier coating systems with modified bond coats. Surface \& Coatings Technology, 203(5-7), 449-455.

Stöver, D, \& Funke, C. (1999). Directions of the development of thermal barrier coatings in energy applications. Journal of Materials Processing Technology, 92-93, 195-202.
Todd, DM. (1989). GE combined cycle experience. In 33rd GD Turbine State-of-the-Art Tech Seminar, Paper No. GER-3585A, USA.

Troczynski, T, Cockcroft, S, \& Wong, H. (1996). Thermal barrier coatings for heat engines. Key Engineering Materials, 122-124, 451-462.

United Nations Economic and Social Commission for Asia and the Pacific (UNESCAP). (2000). Environment and Sustainable Development Division. Part 1: Overview of Cogeneration and its Status in Asia. In Guidebook on Cogeneration as a Means of Pollution Control and Energy Efficiency in Asia. http://www.unescap.org/esd/energy/ publications/detail.asp?id=759'

Walston, WS. (2004). Coating and surface technologies for turbine airfoils. In KA Green, TM Pollock, H Harada, TE Howson, RC Reed, JJ Schirra, \& WS Walston (Eds.), Superalloys 2004 (pp. 579-588). Warrendale, PA: TMS.

Wright, IG, \& Gibbons, TB. (2007). Recent developments in gas turbine materials and technology and their implications for syngas firing. International Journal of Hydrogen Energy, 32, 3610-3621.

Yokoyama, R, Ito, K, \& Murata, T. (2004). Robust optimal design in multistage expansion of a gas turbine cogeneration plant under uncertain energy demands. Journal for Engineering for Gas Turbines and Power - Trans of the ASME, 126(4), 823-830.

Zeren, R. (1982). Technical assessment guide, EPRI P-2410-SR. Palo Alto, CA: EPRI.

Zickler, GA, Schnitzer, R, Radis, R, Hochfellner, R, Schweins, R, Stockinger, M, Leitner, H. (2009). Microstructure and mechanical properties of the superalloy ATI Allvac ${ }^{\oplus}$ 718Plus ${ }^{\text {TM }}$. Materials Science and Engineering A, 523(1-2), 295-303.

doi:10.1186/s40712-014-0002-y

Cite this article as: Huda et al:: Enhancing power output and profitability through energy-efficiency techniques and advanced materials in today's industrial gas turbines. International Journal of Mechanical and Materials Engineering $2014: 2$.

\section{Submit your manuscript to a SpringerOpen ${ }^{\circ}$ journal and benefit from:}

- Convenient online submission

Rigorous peer review

- Immediate publication on acceptance

- Open access: articles freely available online

- High visibility within the field

- Retaining the copyright to your article

Submit your next manuscript at $>$ springeropen.com 